\title{
HIV cell-to-cell spread and innate immune responses
}

\author{
Olivier Schwartz \\ From Frontiers of Retrovirology: Complex retroviruses, retroelements and their hosts \\ Cambridge, UK. 16-18 September 2013
}

Our research is aimed at understanding the interplay between viruses and the immune system. HIV cell-tocell transmission is a major mechanism of viral spread. We are studying how antiviral molecules, such as broadly neutralizing antibodies and restriction factors, known to inhibit infection with cell-free virions, interfere with HIV-1 cell-to-cell transmission. Moreover, we previously showed that HIV-1 infected lymphocytes are more potent inducers of type-1 IFN than free virions. There are target cell-type differences in the recognition of infected lymphocytes. In primary pDCs and pDC-like cells, recognition occurs in large part through TLR7. In myeloid DCs, and other cells that lack TLR7, recognition is independent of TLR7, and occurs in a large part through a cytoplasmic pathway that we are currently analyzing. Finally, we are examining how HIV-2 spreads from cell-to-cell and triggers type-1 IFN in various primary cell types. Characterization of the mechanisms of innate recognition of HIV-infected cells allows a better understanding of the pathogenic and exacerbated immunologic events associated with HIV infection.

Published: 19 September 2013

doi:10.1186/1742-4690-10-S1-034

Cite this article as: Schwartz: HIV cell-to-cell spread and innate immune responses. Retrovirology 2013 10(Suppl 1):034.

Submit your next manuscript to BioMed Central and take full advantage of:

- Convenient online submission

- Thorough peer review

- No space constraints or color figure charges

- Immediate publication on acceptance

- Inclusion in PubMed, CAS, Scopus and Google Scholar

- Research which is freely available for redistribution 